\title{
Papers
}

\section{Cyclin D1 expression and HHV8 in Kaposi sarcoma}

Margaret M Kennedy, Simon Biddolph, Sebastian B Lucas, David D Howells, Steve Picton, James O'D McGee, Ivan Silva, Volker Uhlmann, Karsta Luttich, John J O’Leary

Nuffield Department of Pathology and Bacteriology, University of Oxford, Oxford OX3 9DU, UK M M Kennedy J O'D McGee

Department of Paediatric Pathology, Cellular Pathology, John Radcliffe Hospital, Oxford OX3 9DU, UK S Biddolph

Department of Pathology, UMDS, St Thomas' Hospital, London SE1 7EH, UK S B Lucas

PE Applied Biosystems, Warrington, Cheshire, WA3 7 PR, UK D D Howells

S Picton

Department of Pathology, Coombe Women's Hospital, Dublin 8, Republic of Ireland

J J O'Leary

I Silva

V Uhlmann

K Luttich

Correspondence to: Dr O'Leary

Accepted for publication 5 November 1998

\begin{abstract}
Background-Human herpesvirus 8 (HHV8) appears to be the agent responsible for Kaposi sarcoma. The mechanism remains undetermined but may involve cell cycle regulating genes including D type cyclins which are pivotal in cell cycle progression. Recent HHV8 genetic analysis has revealed the presence of a $\mathrm{v}$-cyclin which is homologous to $D$ type cyclins.

Aims-First, to assess whether there is an independent relation between endogenous cyclin D1 expression in Kaposi sarcoma and HHV8 status; second to determine whether $\mathrm{v}$-cyclin $\mathrm{mRNA}$ expression varies with Kaposi sarcoma stage.

Methods-Cyclin D1 immunohistochemistry was performed on 17 paraffin embedded Kaposi sarcoma samples from 16 patients. HHV8 status was assessed in 15 of these using nested polymerase chain reaction (PCR) to ORF 26 and the newly described technique of TaqMan ${ }^{\circledR}$ PCR. An additional 10 fresh Kaposi sarcoma samples (early and nodular) were examined for HHV8 v-cyclin RNA.

Results-One case, which did not contain amplifiable HHV8, showed strong cyclin D1 staining. The remaining cases were negative or weakly staining; v-cyclin transcript load was higher in early Kaposi sarcoma.

Conclusions-While endogenous cyclin D1 expression is independent of HHV8 status, v-cyclin transcription is higher in early lesions, supporting the "viral hit" hypothesis.

(f Clin Pathol 1999;52:569-573)
\end{abstract}

Keywords: Kaposi sarcoma; cyclin D1; HHV8 v-cyclin

Kaposi sarcoma, a tumour of uncertain histogenesis, has long been considered to be caused by a transmissible infectious agent. ${ }^{1}$ Human herpesvirus 8 (HHV8)/Kaposi sarcoma associated herpesvirus (KSHV) ${ }^{2}$ is generally accepted to be the most likely candidate agent, and this is supported by its strong association with all subtypes of Kaposi sarcoma. ${ }^{3-6}$ It has also been documented in multicentric Castleman disease $(\mathrm{MCD})^{7}$ and primary effusion lymphoma (PEL)(8). However, the mode by which HHV8 is involved in the pathogenesis of Kaposi sarcoma remains unresolved and it is known that many factors are implicated including cytokines, ${ }^{910}$ antiapoptosis genes, ${ }^{11}$ and cell surface receptors, for example CD $40 .^{12}$

HHV8 genome analysis has shown that many homologues of cellular genes are present including genes which encode $\mathrm{Bcl}-2,{ }^{13}$ cytokines, ${ }^{14} \mathrm{G}$ protein coupled receptors, ${ }^{15}$ and a v-cyclin. ${ }^{15-18}$ The latter is known to be homologous to D2 cyclins and has been shown to induce hyperphosphorylation of retinoblastoma protein in transfected cell lines, ${ }^{16}$ which suggests that HHV8 might play a direct role in cell cycle deregulation. The D type cyclins are pivotal molecules in cell proliferation governing cell cycle progression in the G1 phase. Cyclins form complexes with cyclin dependent kinases and mediate their proliferative effect by hyperphosphorylation of checkpoint molecules, for example retinoblastoma protein, thereby inhibiting the function of the latter. ${ }^{19}{ }^{20}$ As cyclins are key molecules in cell cycle progression, we decided to investigate the expression of cyclin D1 in specimens of Kaposi sarcoma from different anatomical sites to establish whether there was a relation with the presence or absence of HHV8 within these lesions. In addition, we hoped to determine whether v-cyclin RNA expression varied with tumour stage.

\section{Methods}

CYCLIN D1 IMMUNOHISTOCHEMISTRY

Immunohistochemical estimation of the cyclin D1 protein product was assessed in 17 specimens from 16 patients (table 1). Eleven patients were HIV positive and the three known HIV negative cases were of African endemic origin. Representative sections were mounted on glass slides coated with Vectabond (Vector Laboratories), dewaxed, and rehydrated. Endogenous peroxidase activity was quenched by incubation in 3\% hydrogen peroxide for 20 minutes.

The sections were placed in a domestic pressure cooker in $0.01 \mathrm{M}$ sodium citrate $(\mathrm{pH}$ 6) buffer and boiled at full pressure for 90 
Table 1 Clinical details (including HHV8 status) and analysis of cyclin D1 protein product

\begin{tabular}{|c|c|c|c|c|c|}
\hline Patient No & HHV 8 & HIV status & Sex & Site & Cyclin D1 \\
\hline 1 & Pos & Pos & $\mathrm{F}$ & Skin, patch & $\begin{array}{l}\text { Neg sp } \\
\text { Neg endo } \\
\text { Neg sp }\end{array}$ \\
\hline & Pos & & & Skin, nodular & Neg endo \\
\hline 2 & Pos & Pos & M & Skin, patch & $\begin{array}{l}++\mathrm{sp} \\
+ \text { endo }\end{array}$ \\
\hline 3 & Pos & Pos & M & Skin, nodular & $\begin{array}{l}+\mathrm{sp} \\
\text { Neg endo }\end{array}$ \\
\hline 4. & Pos & $?$ & $?$ & Skin, patch & $\begin{array}{l}\text { Neg sp } \\
\text { Neg endo }\end{array}$ \\
\hline 5 & $\mathrm{Neg}$ & $\mathrm{Neg}$ & M & Lymph node & $\begin{array}{l}+++\mathrm{sp} \\
+++ \text { endo (focal) }\end{array}$ \\
\hline 6 & Pos & $\mathrm{Neg}$ & M & Skin, patch & $\begin{array}{l}+\mathrm{sp} \\
\text { Neg endo }\end{array}$ \\
\hline 7 & Pos & Pos & M & Skin, patch & $\begin{array}{l}\text { Neg sp } \\
\text { Neg endo }\end{array}$ \\
\hline 8 & Pos & Pos & M & Skin, patch & $\begin{array}{l}\text { Neg sp } \\
\text { Neg endo }\end{array}$ \\
\hline 9 & Neg & Neg & M & Skin, nodular & $\begin{array}{l}\text { Neg sp } \\
\text { Neg endo }\end{array}$ \\
\hline 10 & Pos & Pos & $M$ & Lymph node & $\begin{array}{l}\text { Neg sp } \\
\text { Neg endo }\end{array}$ \\
\hline 11 & Pos & Pos & M & Lung & $\begin{array}{l}\text { Neg sp } \\
\text { Neg endo }\end{array}$ \\
\hline 12 & $\mathrm{~N} / \mathrm{D}$ & Pos & M & Stomach & $\begin{array}{l}\text { Neg sp } \\
\text { Neg endo }\end{array}$ \\
\hline 13 & $\mathrm{~N} / \mathrm{D}$ & Pos & $M$ & Mouth & $\begin{array}{l}+/-\mathrm{sp} \\
+/- \text { endo }\end{array}$ \\
\hline 14 & Pos & Pos & M & Stomach & $\begin{array}{l}\text { Neg sp } \\
\text { Neg endo }\end{array}$ \\
\hline 15 & Pos & $?$ & $?$ & & $\begin{array}{l}\text { Neg sp } \\
\text { Neg endo }\end{array}$ \\
\hline 16 & Neg & Pos & $\mathrm{F}$ & Skin, nodular & $\begin{array}{l}+\mathrm{sp} \\
\text { Neg endo (focal) }\end{array}$ \\
\hline
\end{tabular}

endo, endothelial cell; F, female; HHV8, human herpesvirus 8; M, male; N/D, not done; Neg, negative; Pos, positive; sp, spindle cell; $+/-$ to +++ , degree of positivity.

seconds. $^{21}$ On removal from the pressure cooker, slides were immediately immersed in distilled water and transferred to phosphate buffered saline (PBS).

The sections were subsequently incubated at room temperature for one hour in NCL-cyclinD1-GM monoclonal antibody (clone P2D11F11; 1:25) (Novocastra Laboratories). The slides were then washed and incubated in biotinylated goat antimouse antibody (Dako code No E0433; 1:400) for 30 minutes, followed by a further incubation in streptavidin-HRP (Dako code No P0397) employing diaminobenzidine (DAB) as the chromagen.

Cells were regarded as cyclin D1 positive when there was nuclear staining. Staining was assessed semiquantitatively on a scale from +

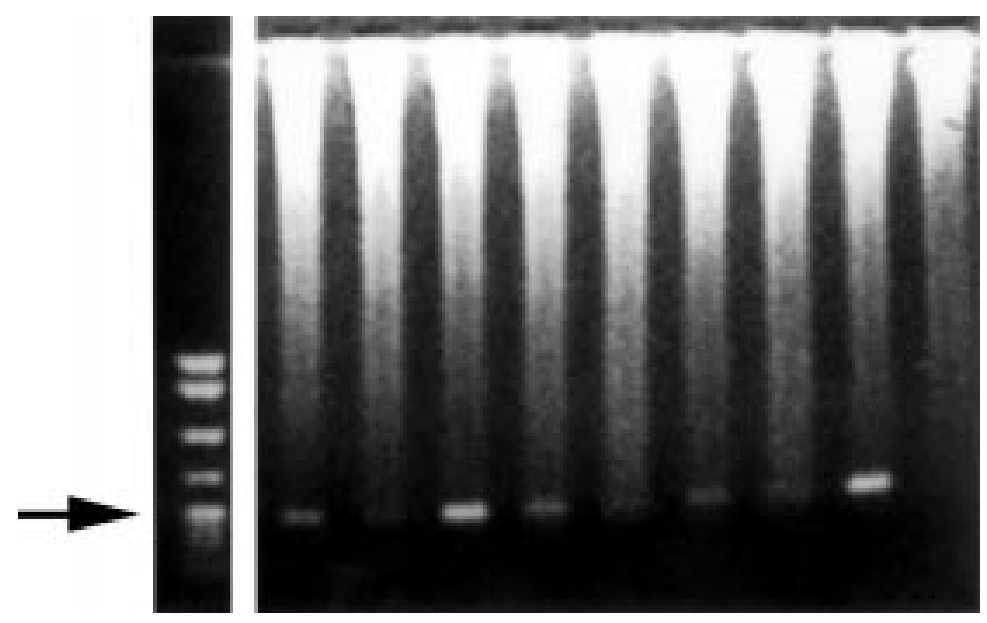

Figure $12 \%$ agarose gel electrophoresis (HHV8 KS 330 Bam). (weak) to ++++ (strong). Both spindle cells and endothelial cells were assessed independently. A case of mantle cell lymphoma was used as positive control material. The primary antibody was omitted in the negative controls.

HHV8 PCR AMPLIFICATION

Representative formalin fixed, paraffin embedded tissue from 15 specimens was dewaxed and placed for three to five days at $37^{\circ} \mathrm{C}$ in proteinase $\mathrm{K}(0.1 \mathrm{mg} / \mathrm{ml})$ digestion buffer $(100 \mathrm{mM}$ $\mathrm{NaCl}, 10 \mathrm{mM}$ Tris, $25 \mathrm{mM}$ ethylene diamine tetra-acetic acid (EDTA), and $0.5 \%$ sodium dodecyl sulphate (SDS), $\mathrm{pH}$ 8.4). The DNA was purified by phenol/chloroform extraction followed by overnight precipitation in $3 \mathrm{M}$ sodium acetate/ethanol. Samples were then centrifuged and resuspended in high performance liquid chromatography (HPLC) water. The quality of DNA was assessed by $\beta$ globin amplification (yielding a 268 base pair fragment).

Nested polymerase chain reaction (PCR) amplification of the open reading frame (ORF) 26 of HHV8 was conducted in a 480 DNA thermal cycler (Perkin Elmer) using the following primer pairs:

Outer set:

KS4 5'-AGCACTCGCAGGGCA GTACG-3' KS5 5'-GACTCTTCGCTGATGAACTGG-3' Inner set:

KS1 5'-AGCCGAAAGGATTCC ACCAT-3' KS2 5'-TCCGTGTTGTCTACGTCCAG-3'

The cycling protocol was as follows:

Outer set $\left(94^{\circ} \mathrm{C} \times 45 \mathrm{~s} ; 60^{\circ} \mathrm{C} \times 30 \mathrm{~s} ; 72^{\circ} \mathrm{C} \times 45\right.$

s) for 25 cycles;

Inner set $\left(94^{\circ} \mathrm{C} \times 45 \mathrm{~s} ; 55^{\circ} \mathrm{C} \times 30 \mathrm{~s} ; 72^{\circ} \mathrm{C} \times 45\right.$

s) for 35 cycles, with a soak file of $4^{\circ} \mathrm{C}$.

Reaction products (233 base pair fragment) were run on a $2 \%$ agarose gel (Sigma) (fig 1).

TAQMAN ${ }^{\circledR}$ PCR

Negative cases were subsequently reamplified using TaqMan PCR which we have described in detail elsewhere. ${ }^{22}$ This technique employs conventional primer pairs in the amplification reaction as well as a fluorescent labelled target specific oligonucleotide probe. During amplification the fluorescent reporter molecule is released by exploiting the 5 ' nuclease activity of AmpliTaq DNA polymerase. The increase in sample fluorescence correlates with the amount of specific product generated and may be detected by a luminescence spectrometer.

For the detection of HHV8, reaction conditions were as previously described ${ }^{22}$ with 300 $\mathrm{nM}$ of each primer (KS1 5'-AGCCGA AAGGATTCCACCAT-3'; KS2 5'-TCCGTG TTGTCTACGTCCAG-3') and $200 \mathrm{nM}$ of TaqMan probe (5' F-CGCTATTCTGCA GCAGCTGTTGGTGTACCA-T 3', where $\mathrm{F}=\mathrm{FAM}$ (6-carboxy-fluorescein) and $\mathrm{T}=$ TAMRA (6-carboxy-tetramethyl-rhodamine)). No template controls were performed in triplicate.

v-CYCLIN RNA AMPLIFICATION

Ten fresh Kaposi sarcoma skin cases (five early/five nodular) were selected (table 2). RNA was extracted using the RNAzol B 
Table 2 Clinical details and HHV8 v-cyclin RNA analysis according to Kaposi sarcoma stage

\begin{tabular}{lllll}
\hline $\begin{array}{l}\text { Case } \\
\text { No }\end{array}$ & Stage & Sex & $\begin{array}{l}\text { HIV } \\
\text { status }\end{array}$ & $\begin{array}{l}\text { v-Cyclin transcripts } \\
\text { /100 ng tRNA }\end{array}$ \\
\hline 1 & Early & M & Pos & 600 \\
2 & Early & M & Pos & 850 \\
3 & Early & M & Pos & 450 \\
4 & Early & M & Pos & 1050 \\
5 & Early & M & Pos & 1167 \\
6 & Nodular & M & Pos & 210 \\
7 & Nodular & F & Pos & 50 \\
8 & Nodular & M & Pos & 230 \\
9 & Nodular & M & Pos & 258 \\
10 & Nodular & M & Pos & 140 \\
\hline
\end{tabular}

F, female; M, male; Pos, positive.

method (Molecular Research Centre Inc). All gene quantitations were performed using the 7700 DNA sequence detector (Perkin Elmer) using $100 \mathrm{ng}$ of extracted total RNA. The following protocol was employed: primers 200 $\mathrm{nM}$, deoxynucleotide triphosphates $300 \mu \mathrm{M}$, TaqMan probe $100 \mathrm{nM}$, rTth polymerase 0.1 $\mathrm{U} / \mu \mathrm{l}$, uracil $\mathrm{N}$-glycosylase $0.01 \mathrm{U} / \mu \mathrm{l}, 1 \times$ TaqMan EZ buffer, manganese acetate $3 \mathrm{mM}$ (Perkin Elmer), with DNase and RNase free water to $50 \mu \mathrm{l}$.

HHV8 v-cyclin gene

Forward primer: 5' ACC AGT TCA CTT TGC TAT GCC 3'

Reverse primer: 5' GCT TTT GTA ATC AGG GTG TTG AC 3'

TaqMan probe: 5' FAM-CAG ACT CCT TTT CCC GCC AAG AAC TTA TAGTAMRA 3'

Reference gene for total RNA

GAPDH was used as the reference gene for tRNA:

Forward primer: 5' GAA GGT GAA GGT CGG AGT 3'

Reverse primer: 5' GAA GAT GGT GAT GGG ATT TC 3'

TaqMan probe: 5' JOE-CCG ACT CTT GCC CTT CGA AC-TAMRA 3'

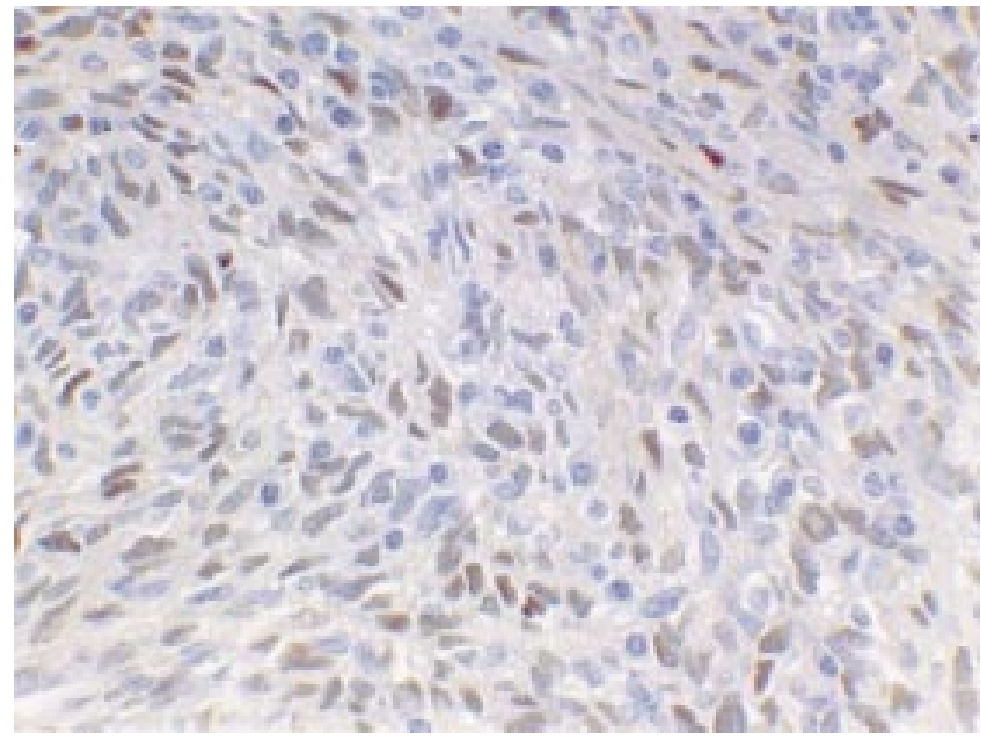

Figure 2 Cyclin D1 immunohistochemistry: nuclear positivity in Kaposi sarcoma nodule (patient No 5).
Thermocycling conditions

The following thermocycling conditions were applied:

$50^{\circ} \mathrm{C} \times 2 \mathrm{~min} ; 60^{\circ} \mathrm{C} \times 30 \mathrm{~min} ; 95^{\circ} \mathrm{C} \times 5 \mathrm{~min}$; $\left[94^{\circ} \mathrm{C} \times 20 \mathrm{~s} ; 60^{\circ} \mathrm{C} \times 1 \mathrm{~min}(\mathrm{v}-\mathrm{cyclin} \mathrm{HHV} 8) /\right.$ $\left.62^{\circ} \mathrm{C} \times 1 \mathrm{~min}(\mathrm{GAPDH})\right] \times 40$ cycles.

$\mathrm{v}$-Cyclin transcript number was calculated using TaqMan PCR employing cloned v-cyclin gene in PCR 2.1 as standards. This assay was repeated in triplicate. GAPDH copy number was then calculated for each $100 \mathrm{ng}$ of RNA used. Sample variability was assessed by reference to the GAPDH result. As the copy number of GAPDH is $2 \times 10^{7}$ per $200 \mathrm{ng}$ of tRNA, the v-cyclin value can then be expressed as the number of transcripts/100 ng total RNA.

STATISTICAL ANALYSIS

The association between viral v-cyclin expression and stage of disease was analysed using the standard $t$ test.

\section{Results}

Of the 17 specimens examined by cyclin-D1 immunohistochemistry, one case showed moderately strong staining (fig 2 ). This staining was focal and is it noteworthy that the patient was negative for HHV8, which was detected in 12 of 15 cases examined. Five specimens showed weak focal positivity (table 1). All other cases were negative. There was minimal or negative staining in adjacent uninvolved tissue. There was no relation to the disease stage or anatomical site. v-Cyclin RNA transcript load was higher in early Kaposi sarcoma lesions (table 2). A significant difference was found between HHV $8 \mathrm{v}$-cyclin gene expression in early and late Kaposi sarcoma biopsy samples $(0.01<\mathrm{p}<0.001)$.

\section{Discussion}

The D cyclins (D1-3) are key cell cycle regulatory molecules governing cell cycle progression in G1 phase. This is mediated by hyperphosphorylation of the retinoblastoma protein, thereby removing the inhibitory function of the latter. ${ }^{19}{ }^{20}$ Cyclin D1, also known as PRAD1, has been localised to chromosome $11 \mathrm{q}^{1} 3^{23}$ and is overexpressed in parathyroid tumours as a result of chromosomal rearrangement. D class cyclins form complexes with cyclin dependent kinases (CDK) which may be inhibited by CDK inhibitors (for example, WAF1-p21) either directly or by a cyclin-CDK complex. ${ }^{20}$ Deregulation of cell cycle control has been implicated in oncogenesis, and abnormal cyclin D1 expression has been documented in diverse tumours including mantle cell lymphoma ${ }^{24-26}$ and carcinomas of the ovary, ${ }^{27}$ endometrium, ${ }^{28}$ and breast. ${ }^{29}{ }^{30}$ Immunohistochemical analysis shows that cyclin D1 is expressed at low levels in normal tissue, being mainly restricted to proliferative zones, for example in stratified squamous epithelia. In addition, there appears to be minimal expression within lymphoid tissue including tonsil, spleen, and lymph node. ${ }^{30}$ 
It is known that following viral infection, host cell defences are activated. These include cell cycle shutdown, apoptosis, and induction of cell mediated immunity. ${ }^{31}$ It is probable that $\mathrm{v}$-cyclins act by inhibiting cell cycle arrest by binding to the retinoblastoma protein.

Recent sequence analysis of the HHV8 genome indicates that ORF 72 encodes a D type cyclin homologue. ${ }^{15-18}$ This ORF shows homology to the ORF 72 of Herpesvirus saimiri which similarly encodes a cyclin D homologue. ${ }^{32}$ In addition, transfected osteosarcoma cell lines have shown that HHV8 $\mathrm{v}$-cyclin is functional and induces hyperphosphorylation of wild type retinoblastoma protein consistent with the inactive form of the protein. ${ }^{16} \mathrm{v}$-Cyclin transcripts have been demonstrated both in Kaposi sarcoma biopsies and effusion lymphomas. ${ }^{15} 163334$ This argues strongly in favour of a direct role for HHV8 in cell cycle deregulation and tumour development.

As cyclin D1 is implicated in the pathogenesis of diverse tumour types, ${ }^{23-30}$ the aim of our study was to assess endogenous cyclin D1 expression in Kaposi sarcoma and to determine whether there was a relation with HHV8 status independent of $\mathrm{v}$-cyclin. While the number of examined cases is small, we have been unable to show a correlation between cyclin D1 expression (as measured by immunohistochemistry) and the presence of HHV8. On the contrary, the single strongly positive specimen was a lymph node which was HHV8 negative on PCR analysis using two different techniques, including TaqMan PCR which we estimate to have a detection sensitivity of one copy in $10^{6}$ contaminating DNA sequences (submitted for publication). The remaining cases were either negative or showed weak focal staining only. In addition, cyclin D1 expression was independent of tumour stage. In contrast, Horenstein and colleagues found that endogenous cyclin D1, which they showed to be antigenically distinct from HHV8 v-cyclin, was more likely to be expressed in late Kaposi sarcoma. ${ }^{35}$

The nature of Kaposi sarcoma is enigmatic and whether it represents a neoplastic or an atypical reactive process is unresolved. ${ }^{36}$ The role of HHV8 is unclear but it is likely that the virus infects target endothelial cells, promoting an inflammatory cascade mediated by cytokines which in some cases allows the emergence of a malignant clone. ${ }^{37} \mathrm{HHV} 8 \mathrm{v}$-cyclin is functional, most homologous to cyclin D2, and known to complex with CDK $6 .{ }^{38}{ }^{39}$ In contrast to cellular cyclins, v-cyclin/CDK complexes are more resistant to inhibition by CDK inhibitor proteins. ${ }^{39}$ We have shown that HHV8 $\mathrm{v}$-cyclin transcripts are higher in early Kaposi sarcoma lesions, which would tend to support the hypothesis that the virus operates a "hit and run" mechanism. At variance with our findings, two separate groups have shown by in situ studies that HHV8 v-cyclin expression is greater in advanced Kaposi sarcoma. ${ }^{33} 34 \mathrm{By}$ contrast, this would support a direct role for HHV8 in Kaposi sarcoma pathogenesis. Additionally, Davis et al conclude that increased
HHV8 v-cyclin expression in late Kaposi sarcoma is likely to promote cell cycle progression, which is in keeping with the higher S-phase fractions documented in nodular lesions. $^{33}$

In summary, we have been unable to correlate the expression of cyclin-D1 with the presence of HHV8 or with tumour stage. In addition, we have shown that v-cyclin expression is greater in early lesions. It is likely that the pathogenesis of Kaposi sarcoma is a complex process involving cell cycle deregulation, cytokines, and apoptosis, functions that may be mediated by viral genes.

JOL acknowledges the support of the Cancer Research Advancement Board, Irish Cancer Society.

1 Beral V. Epidemiology of Kaposi's sarcoma. Cancer Surv 1991;10:5-22.

2 Chang Y, Cesarman E, Pessin MS, et al. Identification of Herpesvirus-like DNA sequences in AIDS-associated Kaposi's sarcoma. Science 1994;266:1865-9.

3 Ambroziak JA, Blackbourn DJ, Herndier BG, et al. Herpeslike sequences in HIV-infected and uninfected Kaposi's sarcoma patients. Science 1995;268:582-3.

4 Huang YQ, Li JJ, Kaplan MH, et al. Human herpesviruslike nucleic acid in various forms of Kaposi's sarcoma. Lancet 1995;345:759-61.

5 Boshoff C, Whitby D, Hatziioannou T, et al. Kaposi's sarcoma-associated herpesvirus in HIV-negative Kaposi's sarcoma. Lancet 1995;345:1043-4.

6 Chang Y, Ziegler J, Wabinga H, et al. Kaposi's sarcomaassociated herpesvirus and Kaposi's sarcoma in Africa. Arch Intern Med 1996;156:202-4.

7 Soulier J, Grollet L, Oksenhendler E, et al. Kaposi's sarcoma-associated herpesvirus-like DNA sequences in multicentric Castleman's disease. Blood 1995;86:1276-80.

8 Cesarman E, Chang Y, Moore PS, et al. Kaposi's sarcomaassociated herpesvirus-like DNA sequences in AIDSrelated body-cavity-based lymphomas. N Engl f Med 1995; 332:1186-91.

9 Stürzl M, Roth WK, Brockmeyer NH, et al. Expression of platelet-derived growth factor and its receptor in AIDSrelated Kaposi's sarcoma in vivo suggests paracrine and autocrine mechanisms of tumor maintenance. Proc Natl Acad Sci USA 1992;89:7046-50.

10 Ensoli B, Nakamura S, Salahuddin SZ, et al. AIDS-Kaposi's sarcoma-derived cells express cytokines with autocrine and paracrine growth effects. Science 1989;243:223-6.

1 Foreman KE, Wrone-Smith T, Boise LH, et al. Kaposi's sarcoma tumor cells preferentially express $\mathrm{Bcl}-\mathrm{X}_{\mathrm{L}}$. Am $\mathcal{f}$ Pathol 1996;149:795-803.

12 Pammer J, Plettenberg A, Weninger W, et al. CD40 antigen is expressed by endothelial cells and tumor cells in Kaposi's sarcoma. Am f Pathol 1996;148:1387-96.

13 Sarid R, Sato T, Bohenzky RA, et al. Kaposi's sarcomaassociated herpesvirus encodes a functional Bcl-2 homologue. Nature Med 1997;3:293-8.

14 Moore PS, Boshoff C, Weiss RA, et al. Molecular mimicry of human cytokine and cytokine response pathway genes by human cytokine and cytokine resp

15 Cesarman E, Nador RG, Bai F, et al. Kaposi's sarcomaassociated herpesvirus contains $\mathrm{G}$ protein-coupled receptor and cyclin D homologs which are expressed in Kaposi's arcoma and malignant lymphoma. F Virol 1996;70:82183

16 Chang Y, Moore PS, Talbot SJ, et al. Cyclin encoded by KS herpesvirus. Nature 1996;382:410.

17 Russo JJ, Bohenzky RA, Chien M-C, et al. Nucleotide sequence of the Kaposi sarcoma-associated herpesvirus (HHV8). Proc Natl Acad Sci USA 1996;93:14862-7.

$18 \mathrm{Li} \mathrm{M}$, Lee H, Yoon D-W, et al. Kaposi's sarcoma-associated herpesvirus encodes a functional cyclin. $\mathcal{F}$ Virol 1997;71: 1984-91.

19 Sherr CJ. Mammalian G1 cyclins. Cell 1993;73:1059-65.

20 Weinberg RA. The retinoblastoma protein and cell cycle control. Cell 1995;81:323-30.

21 Norton AJ, Jordan S, Yeomans P. Brief, high temperature heat denaturation (pressure cooking): a simple and effective method of antigen retrieval for routinely processed tissues. F Pathol 1994;173:371-9.

22 Kennedy MM, Lucas SB, Jones RR, et al. HHV8 and Kaposi's sarcoma: a time cohort study. F Clin Mol Pathol 1997;50:96-100

23 Motokura T, Bloom T, Kim HG, et al. A novel cyclin encoded by a bcll-linked candidate oncogene. Nature 1991;350:512-15.

24 Rosenberg CL, Wong E, Petty EM, et al. PRAD1, a candidate BCL1 oncogene: mapping and expression in centrocytic lymphoma. Proc Natl Acad Sci USA 1991;88: 9638-42.

25 Zukerberg LR, Benedict WF, Arnold A, et al. Expression of the retinoblastoma protein in low-grade B-cell lymphoma: relationship to cyclin D1. Blood 1996;88:268-76. 
26 Jares P, Campo E, Pinyol M, et al. Expression of retinoblastoma gene product $(\mathrm{pRb})$ in mantle cel lymphomas. Correlation with cyclin D1 (PRAD 1/CCND1) mRNA levels and proliferative activity. $A m \mathcal{F}$ Pathol 1996;148:1591-600.

27 Hung W-C, Chai C-Y, Huang J-S, et al. Expression of cyclin D1 and c-Ki-ras gene product in human epithelial ovarian tumors. Hum Pathol 1996;27:1324-8.

28 Nikaido T, Li S-F, Shiozawa $\mathrm{T}$, et al. Coabnormal expression of cyclin D1 and $\mathrm{p} 53$ protein in human uterine expression of cyclin D1 and p53 protein in human
endometrial carcinomas. Cancer 1996;78:1248-53.

29 Bartkova J, Lukas J, Strauss M, et al. Cyclin D1 oncoprotein aberrantly accumulates in malignancies of diverse histogenesis. Oncogene 1995;10:775-8.

30 Bartkova J, Lukas J, Strauss M, et al. Cell cycle-related variation and tissue-restricted expression of human cyclin D1 protein. F Pathol 1994;172:237-45.

31 Shen Y, Shenk TE. Viruses and apoptosis. Curr Opin Genet Dev 1995;5:105-11.

32 Nicholas J, Cameron KR, Honess RW. Herpesvirus saimiri encodes homologues of $\mathrm{G}$ protein-coupled receptors and cyclins. Nature 1992;355:362-5.
33 Davis MA, Sturzl MA, Blasig C, et al. Expression of human herpesvirus 8-encoded cyclin D in Kaposi's sarcoma spindle cells. 7 Natl Cancer Inst 1997;89:1868-74.

34 Reed JA, Nador RG, Spaulding D, et al. Demonstration of Kaposi's sarcoma-associated herpesvirus cyclin D homolog in cutaneous Kaposi's sarcoma by colorimetric in situ hybridization using a catalyzed signal amplification system. Blood 1998;91:3825-32.

35 Horenstein MG, Cesarman E, Wang X, et al. Cyclin D1 and retinoblastoma protein expression in Kaposi's sarcoma. 7 Cutan Pathol 1997;24:585-9.

36 Schulz TF, Weiss RA. Kaposi's sarcoma: a finger on the culprit. Nature 1995;373:17-18.

37 Rabkin CS, Janz S, Lash A, et al. Monoclonal origin of multicentric Kaposi's sarcoma lesions. N Engl f Med 1997;336: 988-93.

38 Godden-Kent D, Talbot SJ, Boshoff C, et al. The cyclin encoded by Kaposi's sarcoma-associated herpesvirus stimulates cdk6 to phosphorylate the retinoblastoma stimulates cdk6 to phosphorylate the retino
protein and histone H1.F Virol 1997;71:4193-8.

39 Swanton C, Mann DJ, Fleckenstein B, et al. Herpes viral cyclin/Cdk6 complexes evade inhibition by CDK inhibitor proteins. Nature 1997;390:184-7. 